EISSN: $2706-7947$ ISSN: 2077- 4613

DOI: 10.36632/mejas/2021.11.1.20

Journal homepage: www.curresweb.com

Pages: 265-276

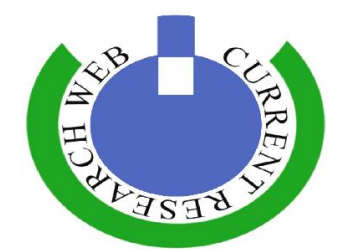

\title{
The Effect of Spraying Boric Acid and Marine Algae Extract on the Growth and Yield of Coriander Plants
}

\author{
Hafiz Y.A.M. and Kenawy A.G.M.
}

Medicinal and Aromatic Plants Research Department, Horticulture Research Institute, ARC, Giza, Egypt

\author{
Received: 05 January $2021 \quad$ Accepted: 28 February $2021 \quad$ Published: 10 March 2021
}

\begin{abstract}
This study was conducted at Sids Horticulture Research Station - Horticulture Research Institute Agricultural Research Center during the seasons 2014/2015 and 2015/2016 under the conditions of North Upper Egypt to study the effect of foliar spraying with boron $\left(0,0.5\right.$ and $\left.1 \mathrm{gl}^{-1}\right)$ and algae extract $\left(0,1,2,3 \mathrm{gl}^{-1}\right)$ and their combinations on coriander plants. The responses of growth characteristics, crop components and some chemical components, with fertilizing coriander with the recommended amount of mineral fertilizer with all foliar treatments (boron compound and algae extract). Results led to a significant improvement as there was a positive effect on various vegetative growth characteristics such as plant height, number of branches and herb dry weight /plant. The best treatments resulted from the treatment $\left(0.5 \mathrm{gl}^{-1}\right.$ of boric acid with $3 \mathrm{gl}^{-1}$ of algae extract), whether in a single condition or in an overlapping condition compared to control. There was a clear and significant improvement in the properties of coriander crops. i.e. the number of fruits per plant and the amount of fruit yield per acre, as well as, essential oil content and oil components. Accordingly it is recommended that spraying coriander plants with a boric acid at a concentration of $0.5 \mathrm{gl}^{-1}$ in combination with $3 \mathrm{gl}^{-1}$ of algae extract improved the vegetative growth, yield components and percentage and quality of volatile oil.
\end{abstract}

Keywords: Coriander, boric acid, algae extract, fruit yield, volatile oil, GC.

\section{Introduction}

Coriander (coriandrum sativum L.) is one of the most important of spices and medicinal plant crops. It is an annual and herbaceous plant, belonging to the Apiaceae family. The coriander seeds have essential oil as an active substance, which is used in Pharmaceutical industry as a antispasmodic and a carminative, diuretic (Diederichen, 1996 and Carrubba et al., 2002). Also used in the preparation of many house hold medicines to cure bed cold, seasonal fever, nausea, and stomach disorders (Rajeshwari and Andallu, 2011). It had been indicated for a number of medical problems in Iranian traditional medicine such as convulsion, dyspeptic complaints, insomnia, loss of appetite, to cure ulcer, inflammation, spasm and acts as an expectorant, protects and soothes liver (Priyadarshi and Borse, 2014). Linalool compound which was the major constituent in the essential oil of $C$. sativum ripe fruits was reported as anti-inflammatory, anti-microbial and sedative properties (Wierdak, 2013).

Boron is an essential element to plant growth, participating in several processes, such as sugar transport, lignifications, cell wall structure, carbohydrate metabolism, RNA metabolism, respiration, indole acetic acid (IAA) metabolism, phenolic metabolism, ascorbate metabolism, besides it has function in cell wall synthesis and plasma membrane integrity according to (Metwally et al., 2017), Boron influences the germination of the pollen grain and pollen tube growth, increases flower glue and granulation, causes less male sterility and less grain puffiness, in addition to flowers and grain formation, B interferes with the retention of newly formed spikes, besides acting on merriest growth, cell differentiation, maturation, cell division and plant growth (Muhmood et al., 2014 and Galindo et al., 2018).

Boron has an efficient role in the growth and production which increases the pollen germination and pollen tube elongation as well as increases the fruit set, the seeds, the fruit development and

Corresponding Author: Kenawy A.G.M., Medicinal and Aromatic Plants Research Department, Horticulture Research Institute, ARC, Giza, Egypt. E-mail: dr.ade176@gmail.com 
production (Abdu-Allah, 2006).Boron increased and changed sugars composition that exists in the nectar where the flowers attract more insects and it influences the pollen production and their viability (Smith and Johnson, 1969 and Eriksson, 1979). (Brown, 2001) found that the foliar spray with boron before flowering is very important which caused a significant increase in the number of hermaphrodite flowers and the fruit set percentage therefore an increase in the production by $20 \%$ comparing with the control treatment.

Algae extract containing some macro and micro nutrients i.e. ( $\mathrm{N}, \mathrm{P}, \mathrm{K}, \mathrm{Ca}, \mathrm{Mg}$ and $\mathrm{S}$ ) and ( $\mathrm{Zn}$, $\mathrm{Fe}, \mathrm{Mn}, \mathrm{Cu}, \mathrm{Mo}$ and $\mathrm{Co}$ ) as well as some growth regulators, polyamines and vitamins required to be applied for improve nutritional status, vegetative growth, yield and fruit quality in different fruits orchards (Abd El-Migeed et al., 2004; Abd El-Moniem \& Abd-Allah, 2008 and Spinelli et al., 2009). (Al-Gosaibi, 1994) stated that applying algae extractions to the soil improving soil characteristics that have a positive impact on nutritional status of plants. In addition, (Whapham et al., 1993) reported that the application of algae extract raised the chlorophyll contents of cucumber cotyledons and tomato plants. The positive effect of algae extract on plant morphology may be due to the presence of many types of plant growth regulators, such as auxins, cytokinins, brassionsteroids, gibberellins and amino acids that have been identified in algae and impact plant growth. Furthermore, algae extract contains all the nutrients and plant growth hormones which are essential plant (Prasaed et al., 2010 and Latique et al., 2013). Also, (Gonzalez et al., 2013) showed that alginate and diverse polysaccharides, some sulphate, stimulate root growth. In addition, (El-Sayed et al., 2018) showed that a spirulina extract contained a higher amount of photo hormones as compared with other natural sources.

The present work was undertaken to foliar application of natural algae extract and boric acid for maximizing yield and improving seed quality of coriander plants under clay soil conditions.

\section{Materials and Methods}

The present investigation was carried out during the two successive seasons of 2014/2015 and 2015/2016 in the Experimental Farm of Horticultural Research Station at Sids, Beni-Sweif Governorate to explore the response of Coriandrum sativum L. plants to foliar application of boric acid ( $17 \%$ boron) and algae extract spray on the plant base at stem elongation stage. Several soil samples $(0-40 \mathrm{~cm}$ depth $)$ were taken for the nutrient and trace element analysis prior to land preparation in (Table, 1) according to Jackson, (1967).

Table 1: Chemical and physical properties of the experimental soil.

\begin{tabular}{|c|c|c|c|c|c|}
\hline \multirow{2}{*}{$\begin{array}{l}\text { Characters } \\
\text { Soil type }\end{array}$} & \multirow{2}{*}{$\begin{array}{c}\text { Value } \\
\text { Clay soil }\end{array}$} & \multicolumn{3}{|c|}{ Character } & \multirow{2}{*}{$\frac{\text { Value }}{40}$} \\
\hline & & Avail & $\mathrm{N}+$ & ppm & \\
\hline Clay $\%$ & 53.3 & Avail. & $\mathrm{P}+$ & ppm & 18 \\
\hline Silt $\quad \%$ & 36.2 & Avail. & $\mathrm{K}+$ & ppm & 336 \\
\hline Sand $\quad \%$ & 10.5 & $\mathrm{Fe}$ & ppm & & 2.40 \\
\hline Org. Matt. \% & 2.23 & $\mathrm{Mn}$ & ppm & & 0.60 \\
\hline $\mathrm{Ca} \mathrm{CO}_{3} \quad \%$ & 3.20 & $\mathrm{Zn}$ & ppm & & 0.20 \\
\hline PH ( $1: 2.5)$ & 7.60 & $\mathrm{Cu}$ & ppm & & 2.00 \\
\hline E.C. $(\mathbf{m} / \mathbf{m h o s} / \mathbf{c m})$ & 0.90 & -------- & $-----\cdot$ & ----- & ------- \\
\hline Exchange K+(meq/l) & 0.8 & Excha1 & ge SO & neq/l) & 7.5 \\
\hline Exchange $\mathrm{Ca}++(\mathrm{meq} / \mathrm{l})$ & 4.0 & Excha1 & ge Cl- & $\mathrm{q} / 1)$ & 1.0 \\
\hline Exchange $\mathrm{Na}+(\mathrm{meq} / \mathrm{l})$ & 2.7 & Excha1 & ge $\mathrm{HC}$ & $(\mathrm{meq} / \mathrm{l})$ & 1.0 \\
\hline Exchange Mg++(meq/l) & 2.0 & Excha1 & ge $\mathrm{CO}$ & $\mathrm{meq} / \mathrm{l})$ & ----- \\
\hline
\end{tabular}

The commercial algae extract (oligo-x) had the following composition; Oligosaccharide (3\%), algnic acid (5\%), phytin $(0.003 \%$ ), natural growth regulators (cytokinine 0.001 , indole acetic acid $(0.002 \%)$ and pepsin $(0.02 \%)$ and minerals (potassium oxide $(12 \%)$, phosphorus oxide $(0.5 \%)$, nitrogen $(1 \%), \mathrm{Zn}(0.3 \%), \mathrm{Fe}(0.2 \%)$ and $\mathrm{Mn}(0.1 \%)$.

Seeds of coriander plants, for experiment, were sown on $1^{\text {st }}$ of October in the two seasons. Each experimental plot was $3.0 \mathrm{~m}$ long with the spacing of $60 \mathrm{~cm}$ between the rows and $30 \mathrm{~cm}$ between hills ( each plot contained 5 rows and 50 hills). Coriander seeds were directly sown by hand in soil. After 
one month from sowing, the plants were thinned to (2) plants per hill. All other agricultural practices were followed as usual.

Split- plot design was also used in this experiment where the main plots were occupied by three concentrations of boric acid while sub- plots were assigned to four concentrations of algae extract compound. Boric acid was applied at the rate of $0,0.5$ and $1 \mathrm{gl}^{-1}$ for each level, the plant leaves was sprayed early in the morning with a 10 liter hand spray and three spraying times during the growing season, as follows: First spray: At the beginning of flowering (85 days after planting). Second spray: At the end of flowering (after1 10 days of planting). Third spray: At the beginning of seed formation (after 125 days of planting).

Algae extract was applied at the rate of $0,1,2$ and $3 \mathrm{gl}^{-1}$ were foliar sprayed four times, 45 days after planting and repeated three times at two weeks intervals through the growing season. In addition, all experimental units, including control, received the recommended rate according to (A. R. C., 2005) of ammonium sulphate ( $300 \mathrm{~kg} / \mathrm{fed}$.) one half of these amounts were applied on the $1^{\text {st }}$ of November (after one month from sowing date), while the other half was applied after one month from the first dose in both seasons., $200 \mathrm{Kg} /$ fed. of calcium super phosphate $\left(15.5 \% \mathrm{P}_{2} \mathrm{O}_{5}\right)$ was added before sowing, while $\mathrm{K}$ at $100 \mathrm{Kg} /$ fed. fertilizer as potassium sulphate $\left(48 \% \mathrm{~K}_{2} \mathrm{O}\right)$ was added in two equal doses, at the beginning of flowering stage and the second one was added three weeks later. The plants were harvested on the first week of April in both seasons.

\subsection{The following data were recorded}

Plant height $(\mathrm{cm})$.

Stem diameter $(\mathrm{mm})$.

Branch number /plant.

Herb dry weight (g /plant).

\subsection{Yield and yield component parameters}

Number of umbels/ plant.

Seed yield / plant and per fed.

\subsection{Chemical constituents}

Total chlorophyll $(\mathrm{mg} / \mathrm{g})$ at flowering stage, leaf samples were collected to estimate photosynthetic pigments according to A.O.A.C., (1996).

Protein content was determined using Micro Kjeldahl method, according to A.O.A.C., (1996).

Total Carbohydrates \% were determined according to the method described by Sadasivam and Manickam, (1996).

\subsection{Volatile oil determinations}

Extraction of coriander fruits essential oil and determined according to Guenther, (1961), Volatile oil constituents using gas chromatography (GC) apparatus DsChrom 6200. analyzed GC by Gomes et al., (2006).

\subsection{Statistical analysis}

Data were statistically analyzed according to MSTAT-C, (1985) program using 2 factor C models - 9; the differences between means were tested by using the least significant differences (L.S.D) test.

\section{Results and Discussion}

\subsection{Effect of boric acid rates on vegetative growth traits}

It is apparent from data in Table (2) that different boric acid concentrations significantly influenced the plant growth character plant height, stem diameter, branches number per plant as well as the total dry weight of coriander plant during the two seasons compared to control. The highest values concerning plant growth characters resulted from the application of boric acid at $0.5 \mathrm{gl}^{-1}$ which increased plant height over the control in the first and second seasons. On the other hand, there were no significant differences between high concentration of boric acid $\left(1 \mathrm{gl}^{-1}\right)$ and the control treatment which increased 
the plant height by $140.8,133.9$ and $141.1,132.4 \mathrm{~cm}$, respectively during the two growing season. This result in line with (Kalyani et al., 1993) who reported that the foliar application of boron as boric acid at 200, 300 and $400 \mathrm{ppm}$. significantly increased the plant height, growth rate and leaf area index in pigeon pea. (Kabir et al., 2013) have reported that application of $\mathrm{P}$ in combination with B significantly increased the plant height and number of branches per plant in groundnut. (Soomro et al., 2011) conducted a field experiment to compare the effect of foliar and soil applied boron on the different growth stages and fodder yield of maize (Zea mays L.) variety Akbar. Experimental results revealed that the foliar application of $0.5 \%$ boron as a boric acid at early, mid and late whorl stages resulted in significant increase in all parameters recorded as compared to soil application boron. (Moniruzzaman et al., 2007) reported that boron application significantly increased plant height, number of leaves per plant, length and width of the leaf, plant spread, main curd weight and curd yield per plant and per hectare up to $1.5 \mathrm{~kg} \mathrm{~B} /$ ha in cauliflower and broccoli. (Devi and Prasad, 2012) conducted an experiment on the effects of application of borax (1 kg/ha) solution on cauliflower and found significant increase in plant height, number of leaves, shoot fresh weight, dry weight, root fresh weight, dry weight and yield. (Shaaban et al., 2006) Found that boron foliar fertilization in a concentration of 25-50 ppm in the spray solution, in combination with $40 \mathrm{~kg}$ nitrogen/fed. as soil treatment has significantly increased plant height, leaf area, total dry weight and number of pods.

\subsection{Effect of algae extract rates on vegetative growth traits}

It is clear from the obtained data that using algae extract significantly improved plant growth characters compared to control (Table 2). The maximum values in this respect were recorded with $3 \mathrm{gl}^{-}$ 1. Though, the abovementioned growth parameters were not significantly affected by foliar application of algae extract up to $2000 \mathrm{mg} / \mathrm{l}$. in both seasons in most cases.

Table 2: Effect of spraying boric acid and seaweed extract on vegetative growth traits of coriander plants during 2014/2015 and 2015/2016 seasons.

\begin{tabular}{|c|c|c|c|c|c|c|c|c|c|c|}
\hline \multirow{4}{*}{ Boric acid } & \multicolumn{10}{|c|}{ Algae extract } \\
\hline & \multicolumn{5}{|c|}{$1^{\text {st }}$ season } & \multicolumn{5}{|c|}{$2^{\text {nd }}$ season } \\
\hline & \multicolumn{10}{|c|}{ Plant height (cm) } \\
\hline & $0 \mathrm{gl}^{-1}$ & $1 \mathrm{gl}^{-1}$ & $2 \mathrm{gl}^{-1}$ & $3 \mathrm{gl}^{-1}$ & Mean(A) & $0 \mathrm{gl}^{-1}$ & $1 \mathrm{gl}^{-1}$ & $2 \mathrm{gl}^{-1}$ & $3 \mathrm{gl}^{-1}$ & $\operatorname{Mean}(\mathrm{A})$ \\
\hline $\mathbf{0} \mathbf{g l}^{-1}$ & 137.7 & 139.7 & 141.3 & 145.5 & 141.1 & 129.3 & 130.3 & 132.7 & 137.1 & 132.4 \\
\hline $0.5 \mathrm{gl}^{-1}$ & 141.9 & 142.3 & 144.7 & 147.5 & 144.1 & 135.0 & 136.0 & 136.3 & 138.7 & 136.5 \\
\hline $1 \mathrm{gl}^{-1}$ & 139.4 & 140.3 & 141.3 & 142.3 & 140.8 & 131.7 & 133.3 & 135.0 & 135.6 & 133.9 \\
\hline Mean $(B)$ & 139.7 & 140.8 & 142.8 & 145.4 & & 132.0 & 133.2 & 134.7 & 137.1 & \\
\hline \multirow[t]{2}{*}{ LSD at 5\% } & \multicolumn{2}{|c|}{ for $(A)=3.9$} & \multicolumn{2}{|c|}{$(\mathrm{B})=2.5$} & B) $=7.9$ & \multicolumn{2}{|c|}{ for $(\mathrm{A})=3.7$} & \multicolumn{3}{|c|}{$(\mathrm{B})=2.4 \quad(\mathrm{AB})=8.1$} \\
\hline & \multicolumn{10}{|c|}{ Stem diameter $(\mathrm{cm})$} \\
\hline $\mathbf{0} \mathbf{g l}^{-1}$ & 0.91 & 0.95 & 0.96 & 1.01 & 0.96 & 0.90 & 0.91 & 0.93 & 0.96 & 0.93 \\
\hline $0.5 \mathrm{gl}^{-1}$ & 0.98 & 0.99 & 1.05 & 1.15 & 1.04 & 0.96 & 0.99 & 1.02 & 1.12 & 1.03 \\
\hline $1 \mathrm{gl}^{-1}$ & 0.98 & 1.01 & 1.05 & 1.09 & 1.03 & 0.95 & 1.03 & 1.05 & 1.08 & 1.03 \\
\hline Mean(B) & 0.96 & 0.98 & 1.02 & 1.08 & & 0.94 & 0.98 & 1.00 & 1.05 & \\
\hline \multirow[t]{2}{*}{ LSD at $5 \%$} & \multicolumn{2}{|c|}{ for $(A)=0.08$} & $(B)=0.05$ & \multicolumn{2}{|c|}{$(\mathrm{AB})=0.19$} & for $(\mathrm{A})$ & .06 & \multicolumn{2}{|c|}{$(B)=0.05$} & $(\mathrm{AB})=0.19$ \\
\hline & \multicolumn{10}{|c|}{ Branch number /plant } \\
\hline $\mathbf{0} \mathbf{g l}^{-1}$ & 5.50 & 5.57 & 5.60 & 5.67 & 5.59 & 5.43 & 5.47 & 5.53 & 5.60 & 5.51 \\
\hline $0.5 \mathrm{gl}^{-1}$ & 6.40 & 6.67 & 7.07 & 8.00 & 7.04 & 6.07 & 6.33 & 6.53 & 7.47 & 6.60 \\
\hline $1 \mathrm{gl}^{-1}$ & 5.80 & 6.60 & 7.00 & 7.20 & 6.65 & 5.60 & 6.27 & 6.47 & 6.73 & 6.27 \\
\hline Mean(B) & 5.90 & 6.28 & 6.56 & 6.96 & & 5.70 & 6.02 & 6.18 & 6.60 & \\
\hline \multirow[t]{2}{*}{ LSD at $5 \%$} & \multicolumn{2}{|c|}{$(A)=1.13$} & $(B)=0.68$ & \multicolumn{2}{|c|}{$(\mathrm{AB})=1.87$} & \multicolumn{2}{|c|}{$(\mathrm{A})=0.82$} & $(B)=0.53$ & \multicolumn{2}{|c|}{$(\mathrm{AB})=1.49$} \\
\hline & \multicolumn{10}{|c|}{ Herb dry weight g/plant } \\
\hline $\mathbf{0} \mathbf{g l}^{-1}$ & 39.7 & 40.3 & 41.3 & 43.0 & 41.1 & 34.7 & 34.7 & 36.3 & 40.3 & 36.5 \\
\hline $0.5 \mathrm{gl}^{-1}$ & 43.3 & 44.0 & 48.3 & 55.0 & 47.2 & 36.3 & 39.3 & 42.3 & 50.0 & 41.7 \\
\hline $1 \mathrm{gl}^{-1}$ & 40.0 & 41.7 & 46.0 & 50.3 & 44.0 & 37.3 & 38.0 & 39.7 & 41.3 & 38.8 \\
\hline Mean(B) & 41.0 & 41.9 & 45.2 & 49.4 & & 36.1 & 37.3 & 39.4 & 43.9 & \\
\hline LSD at $5 \%$ & \multicolumn{2}{|c|}{$(A)=5.8$} & $(B)=4.4$ & \multicolumn{2}{|c|}{$(A B)=10.8$} & \multicolumn{2}{|c|}{$(A)=4.7$} & $(B)=3.5$ & & $(A B)=8.6$ \\
\hline
\end{tabular}

The increased in coriander plants growth characteristics due to application of higher concentration of algae extract $\left(3 \mathrm{gl}^{-1}\right)$ may be attributed to the auxin content of the algae extract which has an effective role in cell division and enlargement. The results agreed with those stated by at (Nour 
et al., 2010) on tomato and (Zodape et al., 2010) on green gram, found similar results regarding to algae extract foliar application on improving total yield in different vegetable crops., (El-Nwehy et al., 2018) concluded that foliar application with $1 \mathrm{gl}^{-1}$ algae extract enhances growth parameters of sunflower. Several authors indicated the positive effect of algae extract (Ali and Mostafa, 2009) on sesame plants, (Mansour et al., 2019a) on faba been plants, (El-sayed et al., 2015) on moringa and alfalfa and (Abd El-Migeed et al., 2004) on coratina olive where, the fresh and dry weight per plant of fed. were achieved by using the algae extract foliar application at the rate of $300 \mathrm{~g} / \mathrm{fed}$.

The interaction between boric acid and algae extract treatments was significant in the two seasons as clearly declared in Table (2). Compared with LSD 5\% the best results were obtained due to the boric acid at $0.5 \mathrm{gl}^{-1}$ plus algae extract at $3 \mathrm{gl}^{-1}$ in the first and second seasons, in comparison with control plants.

\subsection{Effect of boric acid rates on yield components}

The obtained results in Table (3) show that boric acid treatment significantly produced more yield and yield components than that of control plants. Moreover, concentration of $0.5 \mathrm{gl}^{-1}$ significantly produced higher number of umbels, seed yield per plant and fed. and volatile oil percentage than those of untreated control plants. The most effective treatments, in descending order, were $0.5 \mathrm{gl}^{-1}$. This trend proved to be true in the two seasons, but was found that there was no statistically significant relationship between concentration 0.5 and $1 \mathrm{gl}^{-1}$.

Table 3: Effect of spraying boric acid and seaweed extract on number of umbels and seed yield per plant and / fed. of coriander plants during 2014/2015 and 2015/2016 seasons.

\begin{tabular}{|c|c|c|c|c|c|c|c|c|c|c|}
\hline \multirow{4}{*}{ Boric acid } & \multicolumn{10}{|c|}{ Algae extract } \\
\hline & \multicolumn{5}{|c|}{$1^{\text {st }}$ season } & \multicolumn{5}{|c|}{$2^{\text {nd }}$ season } \\
\hline & \multicolumn{10}{|c|}{ Number of umbels / plant } \\
\hline & $\mathbf{0} \mathbf{g l}^{-1}$ & $1 \mathrm{gl}^{-1}$ & $2 \mathrm{gl}^{-1}$ & $3 \mathrm{gl}^{-1}$ & $\operatorname{Mean}(\mathrm{A})$ & $\mathbf{0} \mathrm{gl}^{-1}$ & $1 \mathrm{gl}^{-1}$ & $2 \mathrm{gl}^{-1}$ & $3 \mathrm{gl}^{-1}$ & $\operatorname{Mean}(\mathrm{A})$ \\
\hline $0 \mathrm{gl}^{-1}$ & 47.0 & 49.0 & 48.7 & 49.3 & 48.5 & 44.0 & 47.0 & 45.0 & 46.0 & 45.5 \\
\hline $0.5 \mathrm{gl}^{-1}$ & 49.7 & 55.0 & 55.7 & 60.3 & 55.2 & 45.3 & 48.0 & 50.0 & 56.7 & 50.0 \\
\hline $1 \mathrm{gl}^{-1}$ & 50.7 & 54.0 & 55.3 & 56.3 & 54.1 & 46.0 & 48.0 & 49.3 & 50.7 & 48.5 \\
\hline Mean(B) & 49.1 & 52.7 & 53.2 & 55.3 & & 45.1 & 47.7 & 48.1 & 51.1 & \\
\hline \multirow[t]{2}{*}{ LSD at 5\% } & \multicolumn{2}{|c|}{$(\mathrm{A})=\mathbf{5 . 9}$} & $(B)=3.7$ & \multicolumn{2}{|c|}{$(\mathrm{AB})=9.5$} & \multicolumn{2}{|c|}{$(\mathrm{A})=\mathbf{4 . 5}$} & $(B)=3.7$ & \multicolumn{2}{|r|}{$(A B)=8.4$} \\
\hline & \multicolumn{10}{|c|}{ Seed yield (g/ plant) } \\
\hline $\mathbf{0} \mathbf{g l}^{-1}$ & 15.9 & 16.1 & 16.4 & 17.2 & 16.4 & 15.0 & 15.2 & 15.3 & 16.2 & 15.4 \\
\hline $0.5 \mathrm{gL}^{-1}$ & 17.3 & 17.5 & 18.3 & 20.8 & 18.5 & 16.3 & 16.4 & 17.5 & 18.7 & 17.2 \\
\hline $1 \mathrm{gl}^{-1}$ & 16.2 & 17.3 & 18.2 & 18.5 & 17.6 & 16.1 & 16.4 & 16.8 & 17.3 & 16.7 \\
\hline Mean $(B)$ & 16.5 & 17.0 & 17.6 & 18.8 & & 15.8 & 16.0 & 16.5 & 17.4 & \\
\hline \multirow[t]{2}{*}{ LSD at 5\% } & \multicolumn{3}{|c|}{$(A)=2.1 \quad(B)=1.9$} & \multicolumn{2}{|c|}{$(\mathrm{AB})=\mathbf{3 . 3}$} & \multicolumn{2}{|c|}{ for $(\mathrm{A})=\mathbf{1 . 7}$} & $(B)=1.5$ & \multicolumn{2}{|r|}{$(\mathrm{AB})=\mathbf{3 . 1}$} \\
\hline & \multicolumn{10}{|c|}{ Seed yield (kg /fed.) } \\
\hline $\mathbf{0} \mathbf{g l}^{-1}$ & 638.7 & 642.7 & 654.7 & 690.7 & 656.7 & 600.0 & 609.3 & 613.3 & 649.3 & 618.0 \\
\hline $0.5 \mathrm{gl}^{-1}$ & 693.3 & 700.0 & 733.3 & 833.3 & 740.0 & 652.0 & 657.3 & 701.3 & 746.7 & 689.3 \\
\hline $1 \mathrm{gl}^{-1}$ & 646.7 & 693.3 & 726.7 & 740.0 & 701.7 & 642.7 & 656.0 & 673.3 & 690.7 & 665.7 \\
\hline Mean(B) & 659.6 & 678.7 & 704.9 & 754.7 & & 631.6 & 640.9 & 662.6 & 695.6 & \\
\hline \multirow[t]{2}{*}{ LSD at $5 \%$} & \multicolumn{2}{|c|}{$(\mathrm{A})=82.0$} & $(B)=76.6$ & \multicolumn{2}{|c|}{$(\mathrm{AB})=132.7$} & \multicolumn{2}{|c|}{$(\mathrm{A})=64.5$} & $(B)=55.9$ & \multicolumn{2}{|c|}{$(\mathrm{AB})=112.1$} \\
\hline & \multicolumn{10}{|c|}{ Volatile oil percentage } \\
\hline $\mathbf{0} \mathbf{g l}^{-1}$ & 0.812 & 0.835 & 0.947 & 0.979 & 0.893 & 0.804 & 0.829 & 0.933 & 0.957 & 0.881 \\
\hline $0.5 \mathrm{gl}^{-1}$ & 0.880 & 0.893 & 0.982 & 1.155 & 0.978 & 0.863 & 0.880 & 0.952 & 1.033 & 0.932 \\
\hline $1 \mathrm{gl}^{-1}$ & 0.889 & 0.893 & 1.111 & 1.111 & 1.001 & 0.872 & 0.883 & 0.960 & 1.033 & 0.937 \\
\hline Mean $(B)$ & 0.860 & 0.874 & 1.013 & 1.082 & & 0.846 & 0.864 & 0.948 & 1.008 & \\
\hline LSD at $5 \%$ & \multicolumn{2}{|c|}{$(A)=0.053$} & B) $=0.045$ & \multicolumn{2}{|c|}{$(\mathrm{AB})=0.087$} & \multicolumn{2}{|c|}{$(A)=0.053$} & B) $=0.041$ & \multicolumn{2}{|c|}{$(\mathrm{AB})=0.072$} \\
\hline
\end{tabular}

In harmony with these results the findings of (Gazala et al., 2016) who reported that application of boron at different rates in different crop have shown a positive influence on yield and other agronomic parameters of different crops reflecting the significant of boron in enhancing the yield of different crops., (Soomro et al., 2011) conducted a field experiment to compare the effect of foliar and soil applied boron on the different growth stages and fodder yield of maize (Zea mays L.) variety Akbar. Experimental results revealed that the foliar application of $0.5 \%$ boron as a boric acid at early, mid and late whorl stages resulted in significant increase in all parameters recorded as compared to soil 
application boron., (Mubshar et al., 2012) reported that application of boron at different stages in rice field significantly improved the yield of the crop., (Swain et al., 2015) found that application of micronutrients (boron fertilizers) controls all the physiological activities which helps the maximum fruit yield. Application of borax (1.5-4.0 $\left.\mathrm{kg} \mathrm{ha}^{-1}\right)$ gave significantly larger and heavier fruits and significantly higher curd yield than the other treatments. (Al-Amery et al., 2011 and Tahir et al., 2014) pointed that seed yield of sunflower crop was increased linearly in response to B, and $200 \mathrm{mg} / \mathrm{L} \mathrm{B}$ and $250 \mathrm{mg} / \mathrm{L} \mathrm{B}$ applications gave significant increases in yield compared to the control. (Shaker and Mohammed, 2011) reported that application of $3 \mathrm{mg} / \mathrm{L}$ of B fertilizer significantly led to an increase in head diameter, number of seeds/head, weight of 1,000 seed and seed yield by $4.88 \%, 9.39 \%, 16.15 \%$ and $8.65 \%$ for spring season and by $5.21 \%, 8.67 \%, 16.67 \%$ and $8.46 \%$ for autumn season, respectively, as compared to check treatment. (Renukadevi and Savithri, 2003) who reported that application boron increased significantly the 100 ashen weight of sunflower.

\subsection{Effect of algae extracts rates on yield components:}

Foliar application of algae extract concentrations $1 \mathrm{gl}^{-1}$ up to $3 \mathrm{gl}^{-1}$ increased significantly plant yield and yield components characters compared to control. (Table 3) The maximum values in this respect were recorded with $2 \mathrm{gl}^{-1}$ or $3 \mathrm{gl}^{-1}$ with no significant difference between them, though, the abovementioned yield parameters were not significantly affected by foliar application of algae extract up to $1 \mathrm{gl}^{-1}$ in both seasons in all cases. The use of algae extract increased significantly yield components characters at higher concentrations $\left(2 \mathrm{gl}^{-1}\right.$ and above) and reached maximum at $3 \mathrm{gl}^{-1}$ algae extract compared to control or $1 \mathrm{gl}^{-1}$. In agreement with our results concerning antioxidants were those reported by (Badran, 2016). Who found that spraying Zaghloul date palm with seaweed extract at 2 or $4 \%$ either alone or with silicon were very effective on improving yield and fruit quality (fruit weight, dimensions). (Abd El Moniem and Abd-Allah, 2008) found that application of algal extract at 25 to $100 \%$ had an announced effect on percentages of bud burst and fruiting buds rather than the check treatment. (AbdelAziz et al., 2011) who reported that the application of seaweed had a significant stimulatory effect on yield parameters of Amaranth tricolor plants during two seasons. (Gehan, 2015) on fennel plant that seaweed extract increased number of umbels and fruit yield per plant significantly when compared with the control (without seaweed extract) in both seasons. (Dogra and Mandradia, 2012) mentioned that Seaweed extract was the best in enhancing bulb weight and yield in onion plant.

The interaction between boric acid and algae extract treatments was significant in the two seasons. The best results of the studied traits were obtained due to treating coriander plants with boric acid $0.5 \mathrm{gl}^{-1}$ in combination with the high algae extract $3 \mathrm{gl}^{-1}$ treatment in the two seasons.

\subsection{Effect of boric acid rates on chemical characteristics}

It is clear from the obtained data in Table (4) that spraying the coriander plants with boron were significantly increased in both seasons, in comparison with control plants., statistically significant differences were found between the high and low concentration, and they were in favor of the low concentration. The same trend was obtained in the second season on the studied traits, where it was significantly increased due to the low concentration compared to the high concentration, whilst insignificant differences between boron levels in their impact on total chlorophyll in both seasons. In agreement with these results were the findings revealed by Pandey and Gupta, (2012) reported that the foliar application of boron at $0.05 \%, 0.1 \%, 0.2 \%$ improve the seed quality in terms and storage, seed protein and carbohydrate in black gram .Boron has positive role in transporting carbohydrates from source to sink while its deficiency retards the synthesis of nucleic acids, carbohydrates metabolism and ultimately reduce biomass (Rashid et al., 2004). According to (Han et al., 2008), boron deficiency influence plant growth by reducing enzymatic activities and lowering stomata conductance and $\mathrm{CO}_{2}$ assimilation in plant leaves.

\subsection{Effect of algae extracts rates on chemical characteristics:}

Data presented in Table (4) indicate that treatment of coriander plants with algae extract markedly increased total chlorophyll content in fresh leaves, protein content and total carbohydrates percentage in dried seeds of coriander plant were significantly affected by the plant sprayed with alga extract when compared to the control plants during the two growing seasons. 
It was found that gradually increase due to the increase in alga extract rate, as the high rates (3 $\left.\mathrm{gl}^{-1}\right)$ in the two seasons. The mentioned results were in harmony with those obtained by the capability of alga extract in promoting chemical constituents was reported by (Rayirath et al., 2009) reported that increasing seaweed application rate from 0 up to $3.0 \mathrm{~cm}^{3} / \mathrm{L}$ increased the nitrogen nutrients percentages in leaves of Amaranthus tricolorplants (Zodape et al., 2011) in tomato plants study, the foliar application of algae extract had positive effect on improving chlorophyll content of the leaves, facilitating carbon movement as well as improving net photosynthesis rate may have contributed to the fruit yield in tomato. (Danesh et al., 2012) on cucumber plants foliar application of 10 or $15 \%$ algae extract increased significantly nitrogen, protein and T.S.S percentages in pea seeds. The effect of algae extract on improving biochemical characters of seed protein content was reported by Zodape et al., (2010) on green gram and (Latique et al., 2013) on bean plants. (Mohammed, 2009) demonstrated that there was a positive effect in the improvement of leaf content of chlorophyll especially the treatment of spray with marine algae extract $2 \mathrm{ml} / \mathrm{l}$.

Table 4: Effect of spraying boric acid and seaweed extract on Total chlorophyll, Protein content and carbohydrates of coriander plants during 2014/2015 and 2015/2016 seasons.

\begin{tabular}{|c|c|c|c|c|c|c|c|c|c|c|}
\hline \multirow{4}{*}{ Boric acid } & \multicolumn{10}{|c|}{ Algae extract } \\
\hline & \multicolumn{5}{|c|}{$1^{\text {st }}$ season } & \multicolumn{5}{|c|}{$2^{\text {nd }}$ season } \\
\hline & \multicolumn{10}{|c|}{ Total chlorophyll (mg/g) } \\
\hline & $0 \mathrm{gl}^{-1}$ & $1 \mathrm{gl}^{-1}$ & $2 \mathrm{gl}^{-1}$ & $3 \mathrm{gL}^{-1}$ & Mean(A) & $\mathbf{0} \mathrm{gl}^{-1}$ & $1 \mathrm{gl}^{-1}$ & $2 \mathrm{gl}^{-1}$ & $3 \mathrm{gl}^{-1}$ & Mean(A) \\
\hline $\mathbf{0 \mathbf { g l } ^ { - 1 }}$ & 3.83 & 3.93 & 4.10 & 4.20 & 4.02 & 3.67 & 3.70 & 3.83 & 3.87 & 3.77 \\
\hline $0.5 \mathrm{gl}^{-1}$ & 4.47 & 4.80 & 4.62 & 5.13 & 4.76 & 4.27 & 4.33 & 4.40 & 4.73 & 4.43 \\
\hline $1 \mathrm{gl}^{-1}$ & 4.27 & 4.40 & 4.53 & 4.67 & 4.47 & 4.07 & 4.07 & 4.27 & 4.33 & 4.19 \\
\hline Mean(B) & 4.19 & 4.38 & 4.42 & 4.67 & & 4.00 & 4.03 & 4.17 & 4.31 & \\
\hline \multirow[t]{2}{*}{ LSD at $5 \%$} & \multicolumn{2}{|c|}{$f(A)=0.31$} & (B) $=0.14$ & & $(\mathrm{AB})=0.48$ & $(A)=0$ & & $(\mathrm{~B})=0.11$ & & $(\mathrm{AB})=0.33$ \\
\hline & \multicolumn{10}{|c|}{ Protein \% } \\
\hline $0 \mathbf{g L}^{-1}$ & 9.53 & 9.80 & 10.27 & 10.67 & 10.07 & 9.07 & 9.20 & 9.53 & 10.07 & 9.47 \\
\hline $0.5 \mathrm{gL}^{-1}$ & 11.27 & 11.47 & 12.13 & 12.40 & 11.82 & 10.60 & 11.00 & 11.56 & 11.80 & 11.24 \\
\hline $1 \mathrm{gL}^{-1}$ & 10.33 & 10.53 & 10.87 & 11.13 & 10.72 & 10.67 & 10.87 & 11.00 & 11.20 & 10.94 \\
\hline Mean(B) & 10.38 & 10.60 & 11.09 & 11.40 & & 10.11 & 10.36 & 10.70 & 11.02 & \\
\hline \multirow[t]{2}{*}{ LSD at $5 \%$} & \multicolumn{2}{|c|}{$\mathrm{f}(\mathrm{A})=0.19$} & $(B)=0.11$ & & $(\mathrm{AB})=0.26$ & $(A)=0$. & & $(B)=0.09$ & & $(\mathrm{AB})=0.23$ \\
\hline & \multicolumn{10}{|c|}{ Total Carbohydrates \% } \\
\hline $\mathbf{0} \mathbf{g L}^{-1}$ & 15.60 & 16.13 & 16.60 & 17.53 & 16.47 & 14.73 & 15.13 & 15.80 & 16.27 & 15.48 \\
\hline $0.5 \mathrm{gL}^{-1}$ & 18.40 & 19.07 & 20.85 & 22.13 & 20.11 & 17.67 & 17.93 & 19.00 & 20.07 & 18.67 \\
\hline $1 \mathbf{g L}^{-1}$ & 18.20 & 19.00 & 19.60 & 19.93 & 19.18 & 16.00 & 16.47 & 17.00 & 17.20 & 16.67 \\
\hline Mean(B) & 17.40 & 18.07 & 19.02 & 19.86 & & 16.13 & 16.51 & 17.27 & 17.85 & \\
\hline LSD at 5\% & \multicolumn{2}{|c|}{$(A)=0.85$} & $(B)=0.32$ & & $A B)=1.19$ & $(A)=0$. & & (B) $=0.29$ & & $(A B)=1.05$ \\
\hline
\end{tabular}

The interaction between boric acid and alga extract treatments was significant in both seasons. The highest values of chemical constituents were obtained due boric acid in combination with alga extract treatment as clearly illustrated in Table (4). These one superior combined treatments (boric acid at $0.5 \mathrm{gl}^{-1}$ with alga extract at $3 \mathrm{gl}^{-1}$ gave the highest increase in study adjectives.

\subsection{Essential oil constituent}

Essential oil of coriander fruits was extracted by steam distillation, fractionated and identified by GC technique. The obtained data are tabulated in Table (5), it could be indicated that there are 28 components were isolated from coriander fruits essential oil. Twenty eight components were identified. These identified compounds accounted for $92.04 \%$ of the composition of coriander fruits essential oil. The remaining portion $7.96 \%$ representing 7 unknown constituents. The first chemical group in coriander fruits essential oil was aliphatic terpenes which consisted of one compound namely; $\beta$ myrcene $(0.63 \%)$. This compound was reported as a constituent of coriander essential oil by Misharina, (2001) who found that the amount of that compound was $0.80 \%$ and (Ravi et al., 2006) reported that $\beta$-myrcene as a component of coriander essential oil. $\alpha$-thujene $(0.08 \%)$, sabinene $(0.21 \%), \alpha$ phellandrene $(0.31 \%), \alpha$-terpinene $(0.07 \%)$, dl-limonene $(1.28 \%), \gamma$-terpinene $(3.99 \%)$ and $\alpha$ terpinolene $(0.79 \%)$. These compounds were reported as constituents of coriander essential oil according to Misharina (2001). $\alpha$-pinene (5.02\%), camphene $(2.63 \%)$ and $\beta$-pinene $(3.54 \%)$. 
These results are agreed with (Ravi et al., 2007). cis linalool oxide $(0.31 \%)$, linalool (61.02\%), transgeraniol $(0.24 \%)$ and nerol (1.23\%). (Misharina, 2001) reported that coriander essential oil has much higher amount of linalool as the predominant component arrived to about $69.75 \%$. borneol $(0.16 \%)$, 4-terpineol (0.33\%). All previous fifth groups identical with the compounds that (Misharina, 2001) have been identified camphor (5.36\%). This compound was reported as constituent of coriander essential oil by (Gil et al., 2002). Lineally propionate $(1.07 \%)$, myrtenyl acetate $(0.23 \%)$ citronellyl acetate $(0.07 \%)$, nearly acetate $(0.09 \%)$ and geranyl acetate $(5.48 \%)$. decanal $(0.54 \%)$, 2-decanal $(0.16 \%)$, undecanal $(0.23 \%)$ and 2 -undecanal $(0.15 \%)$. p-cymene $(0.11 \%)$. The above mentioned results agreed with those of (Msaada et al., 2007) who identified $\alpha$-pinene, $\beta$-pinene, $\rho$-cymene, linalool and aldehydes as the main components of coriander essential oil.

Table 5: GC analysis for volatile oils obtained from coriander fruits of control and treated plants with $\left(0.5 \mathrm{gl}^{-1}\right.$ boric acid $+3 \mathrm{gl}^{-1}$ algae extract $)$ treatment.

\begin{tabular}{|c|c|c|}
\hline Compounds & Control & Treated plants \\
\hline B-Myrcene & 0.63 & 0.67 \\
\hline$\alpha$-Thujene & 0.08 & 0.02 \\
\hline Sabinene & 0.21 & 0.27 \\
\hline$\alpha$-Phellandrene & 0.31 & 0.32 \\
\hline$\alpha$-Terpinene & 0.07 & 0.09 \\
\hline d-Limonene & 1.28 & 0.73 \\
\hline$\gamma$-Terpinene & 3.99 & 3.95 \\
\hline$\alpha$-Terpinolene & 0.79 & 0.69 \\
\hline a-Pinene & 5.02 & 4.99 \\
\hline Camphene & 2.63 & 0.68 \\
\hline$\beta$-Pinene & 3.54 & 1.03 \\
\hline Cis linalool oxide & 0.31 & 00.43 \\
\hline Linalool & 61.02 & 69.03 \\
\hline Trans-Geraniol & 0.24 & 01.24 \\
\hline Nerol & 1.23 & 00.87 \\
\hline 4-Terpineol & 0.16 & 0.21 \\
\hline Boreniol & 0.33 & 0.08 \\
\hline Camphor & 2.07 & 4.75 \\
\hline Linalyl Propionate & 1.07 & 0.11 \\
\hline Myrtenyl Acetate & 0.23 & 0.16 \\
\hline Citronellyl Acetate & 0.07 & 0.68 \\
\hline Neryl Acetate & 0.09 & 0.05 \\
\hline Geranyl Acetate & 5.48 & 2.38 \\
\hline Decanal & 0.54 & 0.27 \\
\hline 2-Decenal & 0.16 & 0.19 \\
\hline Un decanal & 0.23 & 0.15 \\
\hline 2-Undecenal & 0.15 & 0.11 \\
\hline$\rho$-Cymene & 0.11 & 2.81 \\
\hline$\rho$-Cymene-8-ol & & 0.15 \\
\hline Total known & 92.04 & 97.11 \\
\hline Total unknown & 07.96 & 02.89 \\
\hline
\end{tabular}

The essential oil obtained from coriander fruits treated with boric acid compound at $0.5 \mathrm{gl}^{-1}$ with alga extract at $3 \mathrm{gl}^{-1}$ in comparison with the chemical composition of coriander fruits essential oil (control). The obtained data were tabulated in Table (5) from these results, it could be indicated that 29 components were isolated from this one treatment coriander essential oil. The identified compounds ( 29 compounds) accounted for $97.11 \%$ of the composition of this treatment. The remaining portion 2.89 $\%$ representing 6 unknown constituents.

The coriander fruits essential oil was aliphatic terpenes which consisted of one compound namely; $\beta$-myrcene $(0.67 \%)$. This compound was reported as a constituent of coriander essential oil by (Misharina, 2001) who found that the amount of that compound was $0.80 \%$ and (Ravi et al., 2007) reported that $\beta$-myrcene as a component of coriander essential oil. $\alpha$-thujene $(0.02 \%)$, sabinene $(0.27 \%)$, $\alpha$-phellandrene $(0.32 \%)$, $\alpha$-terpinene $(0.09 \%)$, dl-limonene $(0.73 \%), \gamma$-terpinene $(3.95 \%)$ and $\alpha$ - 
terpinolene $(0.69 \%)$. $\alpha$-pinene $(4.99 \%)$, camphene $(0.68 \%)$ and $\beta$-pinene $(1.03 \%)$. These results are agreed with (Gil et al., 2002) and (Ravi et al., 2007). cis linalool oxide (0.43\%), linalool $(69.03 \%)$, trans-geraniol (1.24\%) and nerol (0.87\%) (Misharina, 2001) reported that coriander essential oil has much higher amount of linalool as the predominant component arrived to about $69.7 \%$. borneol $(0.08$ $\%)$, 4-terpineol (0.21\%). camphor (4.75\%).

This compound was reported as constituent of coriander essential oil by (Gil et al., 2002). linalyl propionate $(0.11 \%)$, myrtenyl acetate $(0.16 \%)$ citronellyl acetate $(0.68 \%)$, neryl acetate $(0.05 \%)$ and geranyl acetate $(2.38 \%)$. decanal $(0.27 \%)$, 2-decanal $(0.19 \%)$, un decanal $(0.15 \%)$ and 2 -undecanal $(0.11 \%)$. $\rho$-cymene $(2.81 \%)$. $\rho$-cymene- 8 -ol $(0.15 \%)$. The above mentioned results agreed with those of (Msaada et al., 2007) who identified $\alpha$-pinene, $\beta$-pinene, $\rho$-cymene, linalool and aldehydes as the main components of coriander essential oil.

\section{Conclusion and Recommendation}

Boron is a crucial micronutrient and plays an important role in plant growth and development, being mainly involved in carbohydrate metabolism and cell division. The outcome of this review clearly demonstrated that boron being micronutrients contributes immensely to the growth and productivity of agricultural crops, boron has a role in the process of carbon construction and the organization of enzymes and cell division. The appreciable influence of alga extract may be attributed to its effect in increasing cell membrane permeability and promoting plant efficiency in the absorption of nutrients such as nitrogen, which has a direct relation with leaf chlorophyll concentration. Moreover, algae extract may play a role through its content of cytokines in delaying the aging of leaves by reducing the degradation of chlorophyll. In addition, alga extract as a bio-regulator affecting the balance between photosynthesis and respiration processes in plants. It can recommend that, boron at the rate of $0.5 \mathrm{gl}^{-1}$ in combinations with alga extract at the rate of $3 \mathrm{gl}^{-1}$ for obtaining the best growth and productivity of coriander plants.

\section{Reference}

Abd El-Aziz, N.G., M.H. Mahgoub, and H.S. Siam, 2011. Growth, flowering and chemical constituent's performance of Amaranths tricolor plants as influenced by seaweed (Ascophyllum nodosum) extract application under salt stress conditions. J App. Sci. Res., 7: 1472- 1484.

Abd El-Migeed, A.A., A.B. El-Sayed, and H.S.A. Hassan, 2004. Growth enhancement of olive transplants by broken cells of fresh green algae as soil application. Oinufa J. Agric. Res., 29: 723737.

Abd El-Moniem, E.A. and A.S.E. Abd-Allah, 2008. Effect of green algae cells extract as foliar spray on vegetative growth, yield and berries quality of superior grapevines. Am. Euras, J. Agric. and Environ. Sci., 4: 427-433.

Abdu-Allah, A.S., 2006. Effect of spraying some macro and micronutrients on fruit set, yield and fruit quality of Washington Navel orange trees. J. Applied Sci. Res., 2(11):1059-1063.

Al-Amery, M., J.H. Hamza, and M.P. Fuller, 2011. Effect of Boron Foliar application on reproductive growth of sunflower (Helianthus annuus L.). International Journal of Agronomy doi:10.1155/2011/230712.

Al-Gosaibi, A.M., 1994. Use of algae as a soil conditioner for improvement of sandy soils in Al-Ahasa, Saudi Arabia. Journal of Agricultural Sciences, 19:1877-1883.

Ali, K.M. and S.M. Mostafa, 2009. Evaluation of potassium humate and Spirulina platens is as bioorganic fertilizer for sesame plants grown under salinity stress. Egypt J. Agric. Res., 87: 369-388.

A.O.A.C., 1996. Official Methods of Analysis of the Association of Official Analytical Chemists, $15^{\text {th }}$ Ed. Published by A.O.A.C., 2200 Wilson Boulevard Arlington, Virginia 22201 U.S.A.

A. R. C., 2005. Agriculture Research Center. Technical Bulletin No. 984, Cairo, Egypt.

Badran, A. M. F., 2016. Effect of spraying seaweed extract and silicon on yield and fruit quality of Zaghloul date palms grown under sandy soil condition. Assuit J. Agric. Sci., 47(5): (165-174).

Brown, P. H., 2001.Transient nutrients PH and their impact on yield. A Rationale for foliar fertilizers. Acta Hort., (564): 217-223. 
Carrubba, A.L., R.D. Torre, A. Prima, F. Saiano, and G. Alonzo, 2002. Statistical analyses on the essential oil of Italian coriander (Coriandrum sativum L.) fruits of different ages and origins. Journal of Essential oil. Res., 14 (6): 389-396.

Danesh, R.K., S. Bidarigh, E. Azarpour, M. Moraditochaee and H.R. Bozorgi, 2012. Study effects of nitrogen fertilizer management and foliar spraying of marine plant Ascophyllum nodosumextract on yield of cucumber (Cucumis sativus L.). Int. J. Agri. Crop. Sci., 4 (20): 1492-1495.

Devi, B.S. and A. Prasad, 2012. Response of Cole crops by applying boron. Veg. Sci., 18(1): 80-81.

Diederichen, A., 1996. Coriander promoting the conservation and use of underutilized and neglected crops. International Plant Genetic Resources Institute.

Dogra, B.S. and K. Mandradia, 2012. Effect of seaweed extract on growth and yield of onion. Inter. J. of Farm Sci., 2(1): 59-64.

El-Nwehy, S., A. El-Nasharty, and A. Rezk, 2018. Enhance sunflower productivity by foliar application of some plant growth bio-stimulants under salinity conditions. Bio sci. Res., 15: 1763-1768.

El-Sayed, A.B., S.A. Shehata, and S.S. Taha, 2018. Algae extract overcoming the adverse effects of saline stress in hydroponic grown tomato plants. J. Food Agri. Environ., 16: 92-99.

El-Sayed, S.A.A., F.A. Hellal, and O.A. Nofal, 2015. Influence of algae extracts on yield and chemical composition of Moringa and Alfalfa grown under drought condition. Int. J. Environ. 4: 151-157.

Eriksson, M., 1979. The effect of boron on nectar production and seed setting of red clover (Trifolium pretense L.). Swed. J. Agric. Res., 9.37-41.

Galindo, F.S., M.C.M. Teixeira Filho, S. Buzetti, E.H.M. Boleta, W.L. Rodrigues, J.M.K. Santini, A.R.M. Rosa, M.G.Z. Ludkiewicz and V.M. Silva, 2018. Technical and economic viability of wheat with forms of application and doses of boron. J. Ag. Sci. 10(4):306-315.

Gazala, N., S. Upinder and K. Pardeep, 2016. Boron its importance in crop production status in Indian Soils and crop responses to its application. International Journal of Advanced Research, 5: 654600 .

Gehan, G.M., 2015. Improving the growth of fennel plant grown under salinity stress using some Bio stimulants Am. J. Plant Physiol., 10 (2): 77-83.

Gil, A., E.B. De La Fuente, A.E. Lenardis, M. Lopez Pereira, S.A. Suarez, and A. Bandoni, 2002. Coriander essential oil composition from two genotypes grown in different environmental conditions. Journal of Agricultural and Food Chemistry, 50: 2870-2877.

Gomes, P.C.S., H.R.C. Oliveira, A.M.S. Vicente, and M.F. Ferreira, 2006. Transformation and essential oils composition of leaves and stem of Lemon verbena grown in Portugal, Rev. Bras. Pl. Med., Botucatu, 8 (n.esp) 130-135.

Gonzalez, A., J. Castro, and J. Vera, 2013. Seaweed oligosaccharides stimulate plant growth by enhancing carbone and nitrogen assimilation, basal metabolism and cell division. J. Plant Growth Regul., 32: 443-448.

Guenther, E., 1961. 'The essential oils. Vol. I, III, IV, $4^{\text {th }}$ Ed. D. Van No strand Company, Inc. Princeton. New Jersey. Toronto, New York, London.

Han, S., L.S. Chen, H.X. Jiang, B.R. Smith, L.T. Yang, and C.Y. Xie, 2008. Boron deficiency decreases growth and photosynthesis and increases starch and hexodes in leaves of citrus seedlings. Journal of Plant Physiology, 165(13): 1331-1341.

Jackson, M.L., 1967. Soil chemical analysis Printice-Hall of India Private Limited, New Delhi: 144197.

Kabir, R., S. Yeasmin, A.K.M.M. Islam, and M.A.R. Sarkar, 2013. Effect of phosphorus, calcium and boron on the growth and yield of groundnut (Arachis hypogea L.). International Journal of Bio Science Bio Technology, 5(3): 51-59.

kalyani, R., V. Sree Devi, N.V. Satyanarayanaand and K.V. Madhavarao, 1993. Effect of foliar application of boron on crop growth and yield of pigeon pea (Cajanuscajan Millspaugh L.) Indian Journal of Plant Physiology, 4:223-226.

Latique, S., H. Chernane, and M. Mansouri, 2013. Seaweed liquid fertilizer effect on physiological and biochemical parameters of bean plant (Phaseolus Vulgaris variety paulista) under hydroponic system. Euro. Scient J., 9: 174-191.

Mansour, H.A., H.U. Jiandong, and R.N. Hongjuan, 2019 a. Influence of using automatic irrigation system and organic fertilizer treatments on faba bean water productivity. Int. Jgeomate, 62: 256265. 
Metwally, A.M., R.M. El-Shazoly, and A.M. Hamada, 2017. Physiological responses to excess boron in wheat cultivars. Euro. J. Biological. Res., 7(1):1-8.

Mohammed, A.R.S., 2009. Effect of nitrogen fertilization and spraying with seaweed extracts on growth of cucumber plant. Diyala Journal of Agricultural Sciences, 1(2):134-145.

Moniruzzaman, M., S.M. Rahman, and M.A. Rahman, 2007.Effect of boron on yield and hollow stem of cauliflower and broccoli. J. Soil Sci., 1(3):24-29.

Misharina, T.A., 2001. Influence of the duration and conditions of storage on the composition of the essential oil from coriander seeds. Applied Biochemistry and Microbiology, 37 (6): 622-628.

Msaada, K., K. Hosni, M. Ben Taarit, T. Chahed, M. Hammami, and B. Marzouk, 2007. Effects of crops season and maturity stage on the yield and composition of essential oil of coriander (Coriandrum sativum L.. fruit. Medicinal and Aromatic Plant Science and Biotechnology 6 (Special Issue 1), 115-122 @2012 Global Science Books.

MSTAT-C., 1985. A software program for the design, management and analysis of agronomic research experiments. (Version 4.0) Michigan State University.

Mubshar, H., K.M. Ayaz, K.M. Bismillah, F. Muhammad, and F. Shahid, 2012. Boron application improves growth, yield and net economic return of rice. China national rice Research Institute Published by Elsevier Rice Science, 19(3): 259-262.

Muhmood, A., S. Javid, A. Niaz, A. Majeed, T. Majeed, and M. Anwar, 2014. Effect of boron on seed germination, seedling vigor and wheat yield. Soil Environ. 33 (1):17-22.

Nour, K.A., N.T. Mansour, and W.M. Abdelhakim, 2010. Influence of foliar spray with seaweed extracts on growth, setting and yield of tomato .Journal of Plant Production, 1(7): 961-976.

Pandey, N. and B. Gupta, 2012.The impact of foliar boron sprays on reproductive biology and seed quality of black gram. Trace Elem Med Biol. Jan., 27 (1): 58-64.

Prasaed, K., A.K. Das, and M.D. Oza, 2010. Detection and quantification of some plant growth regulators in a seaweed-based foliar spray employing a mass spectro metrictechnique sans chromatographie séparation. J. Agric. Food Chem., 58: 4594-4601.

Priyadarshi, S. and B.B. Borse, 2014. Effect of the environment on content and composition of essential oil in coriander content and composition of essential oil in coriander. International Journal of Scientific \& Engineering Research, 2014; 5(2):57-65.

Rajeshwari, U. and B. Andallu, 2011.Medicinal benefits of (Coriandrum sativum L.) Spatula D.D., 1(1):51-58.

Rashid, A., M. Yasin, M. Ashraf, and R.A. Mann, 2004. Boron deficiency in calcareous soil reduces rice yield and impairs grain quality. International Rice Research Notes, 29(1): 58-60.

Ravi, R., M. Prakash, and K.K. Bhatt, 2006. Aroma characterization of coriander (Coriandrum sativum L.) oil samples. Eur. Food Res. Technol., 6:425-427.

Ravi, R., M. Prakash, and K.K. Bhatt, 2007. Aroma characterization of coriander Coriandrum sativum L.) oil samples. Eur. Food Res. Technol., 225,367- 374.

Rayirath, P., B. Benkel, D.M. Hodges, P. Allan-Wojtas, S. Mackinnon, A.T. Critchley, and J.B. Prithivira, 2009. Lipophilic components of the brown seaweed, Ascophyllum nodosum, enhance freezing tolerance in Arabidopsis thaliana .Planta., 230: 135-147.

Renukadevi, A. and P. Savithri, 2003. Sunflower (Helianthus annuus) oil yield and quality as influenced by boron application. Madras Agric. J., 74:91.

Sadasivam, S. and A. Manickam, 1996. Bio chemical methods, $2^{\text {nd }}$ Ed. New age inter. India.

Shaaban, S.H.A., S.S. Soliman, and H.A. Hamouda, 2006. Nutrient Removal and Physical. Chemical Properties in Samany Date Palm as Influenced by Different Pruning Treatments. J. Appl. Sci. Res., 2(12): 1142-1150.

Shaker, A.T. and S.A. Mohammed, 2011. Effect of Different Levels and Timing on growth, yield and quality of sunflower genotypes of boron foliar application (Helianthus annuus L.)." Mesopotamia J. of Agric. 39 (3): 16-25.

Smith, R.H. and W.C. Johnson, 1969. Effect of boron on White clover nectar production" .Crop Sci. 9: $75-76$.

Soomro, Z.H., P.A. Baloch, and A.W. Gandhai, 2011. Comparative effects of foliar and soil applied boron on growth and fodder yield of Maize. Pak. J. Agri., Agri. Eng. Vet. Sci., 27(1):18-26. 
Spinelli, F., F. Giovanni, N. Massimo, S. Mattia, and C. Guglielmo, 2009. Perspectives on the use of a sea weed extract to moderate the negative effect of alternate bearing in apple trees. J Hort. Sci. Biotech., 17: 131-137.

Swain, H., T.M. Naser and S. Varma, 2015. Effectiveness of soil application of boron on the yield of cauliflower. Agric. and Food Sci., 2(12):246-251.

Tahir, M., M. Younas-Ishaq, A.A. Sheikh, M. Naeem, and A. Rehman, 2014. Effect of boron on yield and quality of sunflower under agro-ecological conditions of Faisalabad (Pakistan). Sci. Agric., 7 (1): 19-24.

Whapham, C.A., G. Blunden, T. Jenkins, and S.D. Hankins, 1993. Significance of betaines in the increased chlorophyll content of plants treated with seaweed extract. Journal of Applied Phycology, 5:231-234.

Wierdak, R.N., 2013. Essential oil composition of the coriander (Coriandrum sativum L.) herb depending on the development stage. Acta. Agrobotanica, 66(1): 53- 60.

Zodape, S.T., M. Soumita, K. Eswaran, M.P. Reddy, and J. Chikara, 2010. Enhanced yield and nutritional quality in green gram (Phaseolus radiate L) treated with seaweed (Kappaphycus alvarezii) extract. Journal of Scientific and Industrial Research, 69: 468-471.

Zodape, S.T, A. Gupta, S.C. Bhandari, U.S. Rawat, D.R. Chaudhary, K. Eswaran, and J. Chikara, 2011. Foliar application of seaweed sap as bio- stimulant for enhancement of yield and quality of tomato (Lycopersicon esculentum Mill.). Journal of Scientific and Industrial Research, 70: 215-219. 